\title{
A FEKETE LYUKAK MEGFIGYELÉSÉNEK ÚJ MÓDSZEREI
}

\section{NEW METHODS OF BLACK HOLE OBSERVATIONS}

\author{
Dálya Gergely \\ PhD-hallgató, MTA-ELTE Extragalaktikus Asztrofizikai Kutatócsoport, Budapest, Eötvös Loránd Tudományegyetem \\ Természettudományi Kar Atomfizikai Tanszék, Budapest \\ dalyag@caesar.elte.hu
}

\begin{abstract}
ÖSSZEFOGLALÁS
A fekete lyukak már a 18. század óta foglalkoztatják a fizikusokat, és manapság a szélesebb közönség is egyre inkább érdeklődik ezen extrém objektumok iránt. Einstein általános relativitáselméletének megjelenését követően sokáig csak matematikai érdekességként gondoltak rájuk, az utóbbi néhány évtizedben azonban létező objektumokként sok mindent sikerült megtudni róluk. A fekete lyukak kutatásában különösen az elmúlt néhány év hozott jelentős áttöréseket, így ebben a cikkben a két legújabb módszert tekintem át: a fekete lyukak gravitációs hullámainak detektálását, valamint a rádiótávcső-hálózatok által végzett képalkotást.
\end{abstract}

\section{ABSTRACT}

Physicists have been fantasized about black holes from the $18^{\text {th }}$ century on, and nowadays these extreme objects come into the focus of attention of the wider audience more and more often. After predicting their existence by Einstein's theory of general relativity, physicists believed that black holes are only mathematical peculiarities of the theory, but in the last decades, we have gathered a large amount of information about these existing objects. The last few years brought several breakthroughs in the research of black holes, so in this article, I am going to outline the two most recent methods of studying them: detecting gravitational waves from coalescing binary black holes, and imaging by radio telescope networks.

Kulcsszavak: fekete lyuk, gravitációs hullám, LIGO, Event Horizon Telescope

Keywords: black hole, gravitational wave, LIGO, Event Horizon Telescope

Már a 18. század fizikusai is elgondolkodtak azon, hogy vajon létezhetnek-e olyan égitestek, amelyek gravitációs tere annyira erős, hogy még a fény sem tud abból elszökni. A lényegi gondolat e mögött az volt, hogy a fényt kis részecskék sokaságaként kezelték, és tulajdonképpen ennek a szökési sebességét számították ki. 
Az elméletben Albert Einstein általános relativitáselméletének színre lépésével történt jelentős előrelépés. Karl Schwarzschild német fizikus a relativitáselmélet ún. vákuummegoldásait kereste, vagyis hogy anyag jelenlétének hiányában milyen módon görbülhet a téridő. 1916-ban talált is egy olyan megoldást, amelyre ma azt mondjuk, hogy fekete lyukat ír le: ez egy nem forgó, töltés nélküli fekete lyuk, amely az elmélet szerint bármiféle anyag jelenléte nélkül is stabilan megmaradhat. A Schwarzschild által talált megoldást évtizedekig pusztán matematikai érdekességnek tartották: attól, hogy egy elmélet megenged valamit, még nem biztos, hogy az a természetben meg is fog jelenni. Végső soron mindig a kísérlet dönt arról, hogy az elmélet jóslata helyes, vagy sem.

Az 1930-as években jelentős előrelépések történtek a kompakt csillagok kutatásában. Szubrahmanjan Csandrasekhar (Subrahmanyan Chandrasekhar) kiszámította, hogy a fehér törpéknek van egy maximális tömegük, amely fölött összeomlanak, és egy (a korszakban hipotetikus) új égitest, neutroncsillag lesz belőlük. Robert Oppenheimer és társai pedig rájöttek arra, hogy a neutroncsillagok tömegének is van felső határa, amely fölött semmilyen fizikai erőhatás nem képes megállítani a csillag összeomlását, így pedig a valóságban is kialakulhat az eddig pusztán az elméletek szintjén létező fekete lyuk. Jocelyn Bell Burnell 1967-ben fedezte fel az első pulzárt, amiről gyorsan bebizonyosodott, hogy egy gyorsan forgó neutroncsillag. Ez újabb lökést adott a fekete lyukak kutatásának: ha neutroncsillagok tényleg léteznek, akkor talán a fekete lyukak is.

A fekete lyukak megfigyelése azért nagyon nehéz, mert nem bocsátanak ki számottevő elektromágneses sugárzást. Így jellemzően a környezetükre gyakorolt hatásból következtethetünk a jelenlétükre. Az első közvetett feketelyuk-megfigyelésre 1972-ig kellett várni, amikor Charles Thomas Bolton, Louise Webster és Paul Murdin egy rakétára szerelt röntgenteleszkóp segítségével felfedezte a Cygnus X-1-nek nevezett erős röntgenforrást. A rendszerben egy fekete lyuk körül kering egy kék szuperóriás csillag, amelyről csillagszél formájában folyamatosan anyag távozik. Ez az anyag a fekete lyuk körül egy akkréciós (tömegbefogási) korongba gyülik, amelyben több millió fokosra felhevülve a röntgentartományban fényesen sugároz. Az ilyen rendszereket röntgenkettősöknek nevezzük. Ma már számos röntgenkettőst ismerünk; ezek némelyikében neutroncsillag, másokban pedig fekete lyuk a kompakt objektum. Ezek azonban mind speciális rendszerek, ilyen módon magányos fekete lyukakat nem tudunk megfigyelni.

A galaxisok közepén másmilyen fekete lyukakat találunk, mint a röntgenkettősökben. Az utóbbiak úgynevezett sztelláris fekete lyukak, vagyis nagy tömegü csillagok életútjának végén keletkeznek, az előbbiek pedig szupernagy tömegü fekete lyukak, vagyis akár több millió-milliárd naptömegüre is hízhatnak. Az ilyen szupernagy tömegü fekete lyukakat a közeli csillagokra kifejtett hatásuk alapján azonosíthatjuk. 1995-től kezdve a csillagászok kilencven csillag sajátmoz- 
gását követték nyomon a Tejútrendszer közepén lévő Sagittarius $A^{*}$ nevü igen erős rádióforrás körül. Az azóta eltelt idő alatt a csillagok némelyike egy teljes keringést hajtott végre elliptikus pályáján, így a pályák paraméterei nagyon pontosan meghatározhatóvá váltak, amiből következtetni lehetett annak az objektumnak a tömegére, amely körül keringenek. A számításokból tudjuk, hogy a Tejútrendszer közepén egy 4,3 millió naptömegủ égitest helyezkedik el, amit nehéz bármi másként, mint fekete lyukként értelmezni.

Valószínűleg a legtöbb galaxis közepén egy, a Tejútrendszer fekete lyukához hasonló objektum helyezkedik el. Néhány galaxis központi régiójából pedig sokkal intenzívebb sugárzást észlelünk, ezeket aktív galaxisoknak nevezzük. Az aktív galaxisok központi fekete lyuka körül (a röntgenkettősökhöz hasonlóan) egy akkréciós korongot találunk, amely fényesen sugároz az elektromágneses színkép széles tartományában. Bizonyos esetekben ez a fekete lyuk az akkréciós korongra merőlegesen két anyagkilövellést (jetet) is kibocsát, amelyek leginkább a rádiótartományban észlelhetőek (lásd Gabányi Krisztina Éva tanulmányát e lapszám 895. oldalán).

A fekete lyukak észlelésének legelterjedtebb módszerei tehát ezek voltak egészen néhány évvel ezelöttig. Napjainkban két jelentős áttörés is született e területen: a gravitációs hullámok megfigyelésével információkat szerezhetünk az egymás körül keringő fekete lyukakról, míg az Event Horizon Telescope (EHT) nagyon hosszú bázisvonalú interferometria (very long baseline interferometry, VLBI) alkalmazásával képet tudott alkotni egy fekete lyukról. A továbbiakban ezt a két új megfigyelési módot tekintjük át.

A fekete lyukakhoz hasonlóan a gravitációs hullámok is Albert Einstein általános relativitáselméletének jóslatai. Ezeket a hullámokat a téridő rezgéseiként tudjuk leírni: ahogy a tömeggel bíró testek meggörbítik a téridőt, mint egy golyó a gumilepedöt, ha két nagy tömegủ test kering egymás körül, hullámzást fognak létrehozni a téridő szövetén. Ez a hullámzás fénysebességgel terjed tova a forrástól.

Ahhoz, hogy jobban megérthessük, hogy mit is jelent a téridő hullámzása, vizsgáljuk meg, hogy mi történne, ha egy emberen áthaladna egy szemböl érkező ilyen hullám! A körülötte állók azt láthatnák, ahogy az ember egyszer csak megnyúlik, és közben vékonyabb lesz, majd alacsonyabb és szélesebb lesz, és ez periodikusan folytatódik. A hétköznapi életben mégsem látunk ilyesmit, mivel a gravitációs hullámok nagyon csekély megnyúlást és összehúzódást okoznak. A megnyúlás mértéke arányos a test méretével, például egy $1 \mathrm{~m}$-es test kb. $10^{-20} \mathrm{~m}$-rel nyúlna meg, amely egy atommag méretének is töredéke!

Ha csupán ilyen kis mértékủ változásokat okoz a hullám, akkor mégis hogyan lehet kimérni? Az első ilyen irányú kísérletek az 1960-as években indultak. Joseph Weber készítette el az első tömegrezonátornak nevezett detektort, egy két méter hosszú, egy méter átmérőjü tömör alumíniumhengert. Weber egy vákuum- 
kamrába helyezte a detektort, ahol az védve volt a külső rezgésektől. A mérés elve a következő: egy áthaladó gravitációs hullám periodikus megnyúlást és öszszehúzódást okozva megrezgetné a hengert, és ha a hullám frekvenciája közel áll a henger sajátfrekvenciájához, akkor rezonancia lép fel, vagyis a hullám hatása sokkal nagyobb lesz, és így esetleg ki lehet mutatni a henger méretének kicsiny megváltozását, például egy piezoelektromos kristállyal. Weber 1969-re több ilyen detektort is épített, és bejelentette, hogy két detektorral koincidenciában észlelt egy jelet, vagyis gravitációs hullámot talált. Más csoportoknak azonban mind ez idáig nem sikerült tömegrezonáns detektorokkal gravitációs hullámokat kimutatni, így valószínü, hogy a Weber által észlelt jel sem asztrofizikai eredetủ volt. Az ilyen típusú detektorok nagy hátránya az, hogy csak bizonyos szűk frekvenciatartományokon képesek az észlelésre. Emiatt manapság főként egy másik módszert, a lézerinterferometriát használják.

Egy lézerinterferométer két hosszú, egymásra merőleges karból áll, amelyek L alakban helyezkednek el, és bennük ultraalacsony nyomás van. Az L alak közepén egy nyalábosztó van, amelyre egy lézersugarat irányítunk. A nyalábosztóról a sugár egy része az egyik, másik része a másik karba kerül, majd azokon végighaladva elér a végpontokban felfüggesztett tükrökhöz. A tükörről visszaverődő sugarak ezután visszafelé is megteszik az utat, majd a nyalábosztón egyesülnek, és az így újraegyesített fénysugár egy detektorra esik. A karokat úgy alakították ki, hogy a fénysugarak éppen ellentétes fázisban érkezzenek vissza a nyalábosztóra, vagyis teljes kioltás legyen, és semmilyen fény ne essen a detektorra. Azonban ha a rendszeren gravitációs hullám halad át, az hol az egyik, hol a másik kart nyújtja meg kissé, ennek következtében a bennük terjedö fénysugárnak kissé hosszabb vagy rövidebb időre van szüksége, hogy a nyalábosztóra érkezzen. Emiatt pedig kis fáziskülönbség lép fel, vagyis már nem alakul ki teljes kioltás. A detektorra jutó kis fény intenzitásának időbeli változásával mutathatjuk ki a gravitációs hullámot.

Több ilyen felépítésü detektor is üzemel világszerte, ami két szempontból is kulcsfontosságú. Egyrészt a felfedezések megerősítése miatt: ha két detektor közel azonos időpontban észlelt hasonló jelet, akkor az valószínűleg tényleg valamilyen asztrofizikai forrásból származott, és nem csak helyi hatásról, például egy kisebb földmozgásról van szó. Másrészt a több detektor általi észlelés fontos a forrás meghatározásának szempontjából is. A lézerinterferométerek ugyanis nemcsak egy irányból, hanem szinte bármerről képesek érzékelni a hullámokat. Ez abból a szempontból jó, hogy több jelet észlelhetünk, másrészt viszont nagyon megnehezíti a forrás pozíciójának meghatározását. Több detektor használatával azonban a hullámok véges terjedési sebességét kihasználva háromszögeléses módszerrel mégis behatárolható, hogy melyik égterületröl jöhetett a jel.

A gravitációs hullámok kutatásának jelenlegi legérzékenyebb eszközei a két amerikai LIGO- (Laser Interferometer Gravitational-Wave Observatory) detek- 
tor, amelynek karjai 4 km hosszúak (1. ábra). A LIGO-detektorokkal szorosan együttműködik az olaszországi Virgo-, és az ezeknél jóval kisebb németországi GEO600-detektor. Jelenleg tesztelés alatt áll egy új, kriogenikus detektor Japánban (KAGRA), valamint Indiában is épül egy újabb LIGO-detektor.

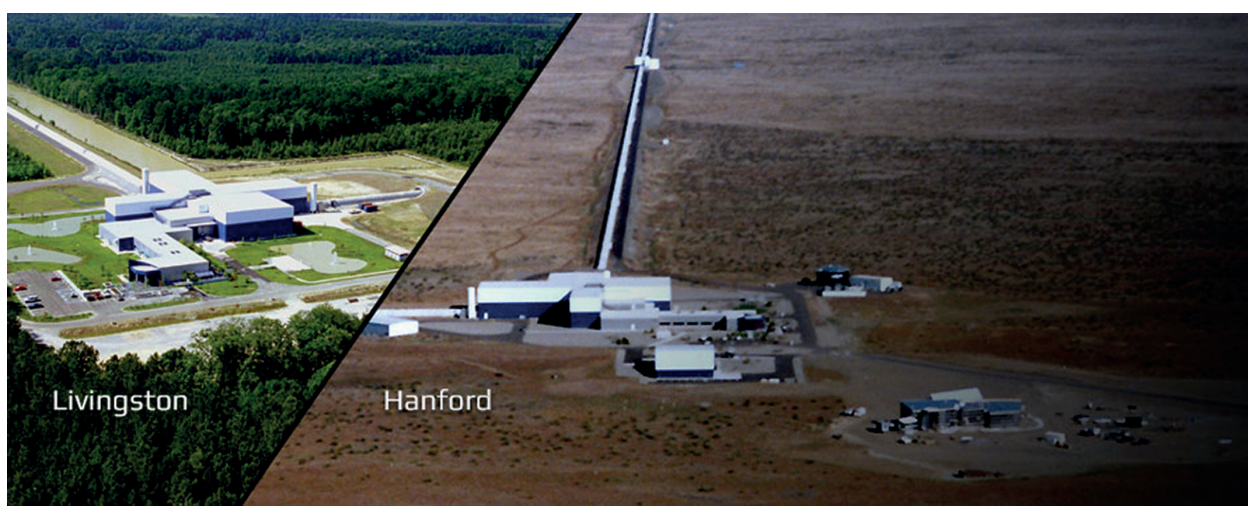

1. ábra. A LIGO két gravitációshullám-detektora Hanfordban és Livingstonban (LIGO; CC BY licensz)

A LIGO-detektorok először 2015. szeptember 14-én észleltek gravitációs hullámokat, amelyek egymás körüli keringő két fekete lyuk összeolvadásából származtak. A 29 és 36 naptömegü fekete lyukak összeolvadása után egy nagyobb, 62 naptömegủ fekete lyuk jött létre, vagyis a folyamat során 3 naptömegnyi energia sugárzódott ki gravitációs hullámok formájában, mindez egytized másodperc alatt. İgy ez az emberiség által észlelt legnagyobb teljesítményü folyamat! Az öszszeolvadás tőllünk kb. 1 milliárd fényév távolságban történt, vagyis a gravitációs hullám már egymilliárd éve úton volt felénk.

A LIGO első két megfigyelési időszaka alatt (amelyekre O1 és O2 néven hivatkoznak), vagyis 2017 szeptemberéig tíz másik gravitációs hullámot is sikerült detektálni, amelyek közül egy neutroncsillagok összeolvadásából, míg a többi az első felfedezéshez hasonlóan fekete lyukak összeolvadásából keletkezett. Az észlelések új ablakot nyitottak az Univerzumra: mivel a gravitációs hullámok az elektromágneses jelektől teljesen független információhordozók, általuk olyan folyamatokat ismerhetünk meg, amelyeket más, hagyományosabb eszközökkel képtelenek lennénk. Ezt az áttörést ismerték el, amikor a LIGO-kollaboráció három vezető személyisége, Rainer Weiss, Kip Thorne és Barry Barish elnyerte a 2017-es fizikai Nobel-díjat.

Rögtön az első felfedezések újdonságokkal szolgáltak a fekete lyukak jobb megértéséhez. Mind ez idáig nem tudtuk, hogy vajon két fekete lyuk ténylegesen összeolvadhat-e egymással, valamint olyan tömegủ fekete lyukakat sikerült így 
megfigyelni, amilyeneket korábban még nem találtunk. A röntgenkettősök megfigyeléséből kb. 5-20 naptömeg közötti tömegü fekete lyukakat fedeztünk fel, míg a galaxisok közepén lévő fekete lyukak tömege ezeknél nagyságrendekkel nagyobb. A LIGO által észlelt folyamatokban pedig 60-80 naptömegü fekete lyukak is keletkeztek, ám az továbbra is válaszra váró kérdés, hogy vannak-e például néhány ezer naptömegű fekete lyukak.

Jelenleg a LIGO harmadik megfigyelési időszaka zajlik, amelynek során már eddig is sok érdekes eseményt észleltek a detektorok. A müszer érzékenységét folyamatosan növelik, valamint várhatóan néhány éven belül a japán KAGRA-detektor is megkezdi müködését, így a következő évtizedben szinte mindennapossá válhat a gravitációs hullámok észlelése.

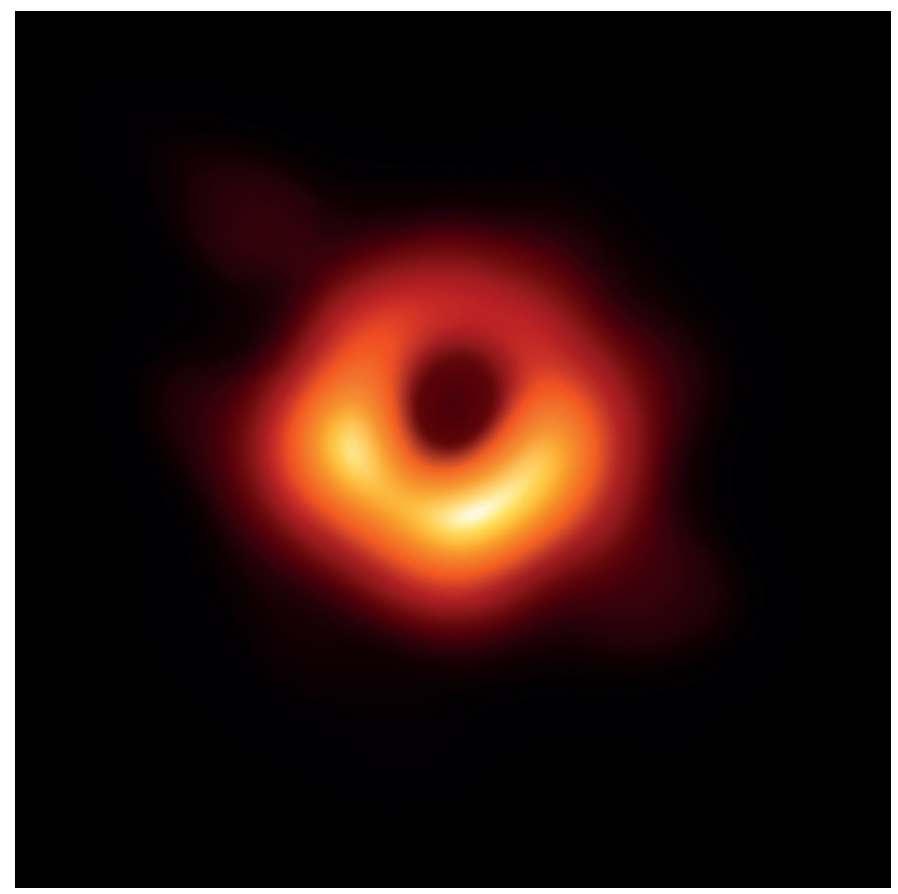

2. ábra. Az Event Horizon Telescope felvétele az M87 szupernagy tömegü fekete lyukáról (ESO; Wikimedia Commons)

A fekete lyukak megfigyelésének másik közelmúltbeli újdonsága az Event Horizon Telescope rádióteleszkóp-hálózat eredménye. A 2009-ben indított nagyszabású projektben tízévnyi munka után, 2019 áprilisában mutatták be az első felvételt, ami egy fekete lyukról készült a nagyközönségnek. A kép az M87 óriás elliptikus galaxis közepén lévő fekete lyukról készült (2. ábra). A felvételen a fekete lyuk 
akkréciós korongja jól kivehető, előtte pedig tulajdonképpen a fekete lyuk „árnyékát" láthatjuk. Ez a kép jóval több, mint pusztán egy érdekesség, az általános relativitáselmélet jóslatait is lehetett általa tesztelni, és ismét megbizonyosodhattunk róla, hogy az kiállja a kísérletek próbáját: tényleg ilyen képet várnánk egy nagy tömegü, forgó fekete lyukról. Az Event Horizon Telescope kollaboráció az adatokból meg tudta határozni a fekete lyuk tömegét is, amelyre kb. 6,5 milliárd naptömeget kaptak. Ez nem teljesen egyezik meg az objektum körül áramló gáz megfigyeléséből számított értékkel, így érdekes asztrofizikai kérdéseket is felvet az elkészült kép. A kollaboráció tervei szerint pedig hamarosan a Tejútrendszer közepén lévő fekete lyukról is elkészül a felvétel.

A gravitációs hullámok észlelése és a VLBI-technológia alkalmazása tehát máris sok fontos kérdés megválaszolásában segített a fekete lyukakkal kapcsolatban, az elkövetkező években pedig mindkét új módszertől további fontos eredményeket várhatunk.

Munkámat az Emberi Erőforrások Minisztériumának ÚNKP-18-3 pályázata támogatta. 